\title{
Short- and long-term natural regeneration after windthrow disturbances in Norway spruce forests in Bulgaria
}

\author{
Nickolay Tsvetanov ${ }^{(1)}$, \\ Alexander Dountchev ${ }^{(1)}$, \\ Momchil Panayotov ${ }^{(1)}$, \\ Peter Zhelev ${ }^{(1)}$, \\ Peter Bebi ${ }^{(2)}$, \\ Stefan Yurukov ${ }^{(1)}$
}

\begin{abstract}
Norway spruce forests are among the forests most affected by natural disturbances in Europe. One of the key aspects is the regeneration of the disturbed areas, which is decisive for later forest development. We studied the natural regeneration after two windthrows that occurred 30 (1983) and 50 years ago (1962) in an old-growth forest over 150-year-old in the Parangalitsa Reserve and a recent windthrow (2001) in a 130-year-old single cohort forest in the Bistrishko branishte Reserve in Bulgaria. We set up study plots along transects, counted regeneration and substrates, and analyzed age using tree rings. Postdisturbance regeneration made up $\mathbf{6 2 - 8 1 \%}$ of all recorded trees and was more important than advance regeneration, but it strongly differed among the windthrows. Our data indicated two discrete peaks of post-disturbance regeneration. The first peak started immediately after the windthrows and was dominated by Norway spruce and rowan, while the second one started about 30 years later and was dominated by spruce. Pioneers such as Populus tremula, Salix caprea and Pinus sylvestris were less prominent than expected, contributing up to $21 \%$ of the total regeneration. Despite the fact that the highest density of initial regeneration was found on mounds from uprooted trees, the largest total number in the three studied areas was on intact forest floor, which hosted between 69 and $80 \%$ of all regeneration. The importance of coarse woody debris rose significantly two to three decades after the disturbances and was particularly important for the secondary regeneration, which consisted of Picea abies and Abies alba.
\end{abstract}

Keywords: Picea abies, Natural Regeneration, Windthrows, Natural Disturbances, Southeastern Europe

\begin{abstract}
Introduction
Norway spruce (Picea abies Karst.) is one of the most important tree species in Europe, including mountain forests in the central and southern parts of the continent. Besides playing a key ecological role, these forests are very important for timber production and, in certain areas, for their protective functions against avalanches, rockfall and soil erosion (Brang et al. 2006, Bebi et al. 2009). At the same time, mountain Norway spruce forests are characterized by a specific disturbance regime (Schelhaas et al. 2003, Kulakowski \& Bebi 2004, Zielonka et al. 2010, Panayotov et al. 2011a, Temperli et al. 2013, Svoboda et al.

2014, Panayotov et al. 2015), which makes their management a challenging task. In the last decades large-scale disturbances, such as windthrows and the following bark beetle outbreaks, have affected nearly 1 million hectares of spruce forests in managed and protected areas across all parts of Western Europe (Lässig \& Schönenberger 2000, Siegrist 2000, Schelhaas et al. 2003, Keidel et al. 2008, Heurich 2009), Central Europe (Fischer et al. 2002, Zielonka et al. 2010, Svoboda et al. 2011), Eastern Europe (Kozulko 2002, Panayotov et al. 2011a, Svoboda et al. 2014, Trotsiuk et al. 2014, Panayotov et al. 2015), and Scandinavia (Skogsstyrelsen 2005).
\end{abstract}

(1) University of Forestry, Dendrology Department, Kliment Ohridski 10 Blvd., 1797 Sofia (Bulgaria); (2) WSL Institute for Snow and Avalanche Research SLF, Flüelastrasse 11, 7260 Davos Dorf (Switzerland)

\section{@ Nickolay Tsvetanov (nicktsvetanov@ltu.bg)}

Received: Feb 07, 2018 - Accepted: Jul 24, 2018

Citation: Tsvetanov N, Dountchev A, Panayotov M, Zhelev P, Bebi P, Yurukov S (2018). Shortand long-term natural regeneration after windthrow disturbances in Norway spruce forests in Bulgaria. iForest 11: 675-684. - doi: 10.3832/ifor2754-011 [online 2018-10-23]

Communicated by: Emanuele Lingua
Despite their severe impacts, natural disturbances represent an important part of mountain Norway spruce forest dynamics (Attiwill 1994, Svoboda et al. 2011). Disturbances such as windthrows and bark beetle outbreaks leave legacies of pre-existing tree regeneration (i.e., advance regeneration), which can contribute to the persistence of the climax species within the forest (Fischer et al. 2002, Schönenberger 2002, Kulakowski \& Veblen 2003 Heurich 2009). In the case of Norway spruce in particular, small understory trees and saplings may keep their vitality under the canopy for many years (San-Miguel-Ayanz et al. 2016, Leuschner \& Ellenberg 2017) and then grow rapidly when light conditions improve after a disturbance. However, when advance regeneration is sparse, such as in younger forests, or when the disturbed area is larger than the dispersal of spruce seeds can cover, the regeneration of the disturbed forest can be dominated by pioneer species.

Understanding the role of natural disturbances within long-term forest dynamics, a part of which is post-disturbance regeneration, is increasingly important in terms of evolving management strategies and anticipated climate changes (Dale et al. 2001, Seidl et al. 2011, Donato et al. 2016). These changes are likely to seriously affect Nor- 
way spruce forests (Kölling et al. 2007). In the past, forest restoration processes after disturbances were usually guided by forest managers by harvesting the wood and planting saplings of desired species. In the last decades, however, there has been a tendency to increase the role of close-tonature silviculture systems, which rely more on natural regeneration processes. Particularly in strict forest reserves and in the core areas of national parks, natural processes after large-scale disturbances are often left without silvicultural interventions. This raises many questions about the ability of the disturbed forests to recover without human assistance and fulfill their protection functions (Siegrist 2000, Schönenberger 2002, Jonášová \& Prach 2004, Keidel et al. 2008, Heurich 2009). At the same time, studying the recovery processes in unmanaged natural spruce forests can provide extensive, valuable information about the ecology and resilience of spruce ecosystems to natural disturbances, which is of key importance for the sustainable management of both managed and protected forests (Krauchi et al. 2000, Kuuluvainen 2002, Kulakowski \& Bebi 2004, Brang et al. 2006).

Recovery processes after large-scale windthrows in spruce forests are very well studied in Northern (Kuuluvainen \& Kalmari 2003, Vodde et al. 2010, Kuuluvainen \&
Aakala 2011) and Central Europe (Fischer et al. 2002, Wohlgemuth et al. 2002, Svoboda et al. 2010, Jonášová et al. 2010). However, most studies cover shorter periods (e.g., 10 to 20 years) after disturbances, and there is therefore a lack of information on the longterm perspective of natural recovery (Jehl 2001, Fischer et al. 2002, Wohlgemuth et al. 2002, Keidel et al. 2008, Heurich 2009, Jonášová et al. 2010, Vodde et al. 2010). Little is known about forest dynamics related to wind-disturbance in Southeastern European mountains. For instance, the subalpine Picea-dominated forests on the Balkan Peninsula (1400-2000 $\mathrm{m}$ a.s.l.), which represent the most southern part of the distribution of Picea abies, are characterized by a high level of naturalness, a specific species composition (e.g., presence of endemic tree species such as Pinus peuce, Pinus heldreichii and Acer heldreichii) and a high susceptibility to wind disturbances (Panayotov et al. 2015). Some of these forests are in protected areas with limited or no intervention, making it possible to conduct long-term studies of the natural processes and particularly of regeneration after disturbances, which can be a long process in subalpine forests.

The aim of this study was to explore the regeneration processes after stand-replacing disturbances in subalpine Norway spruce forests in Southeastern Europe. We

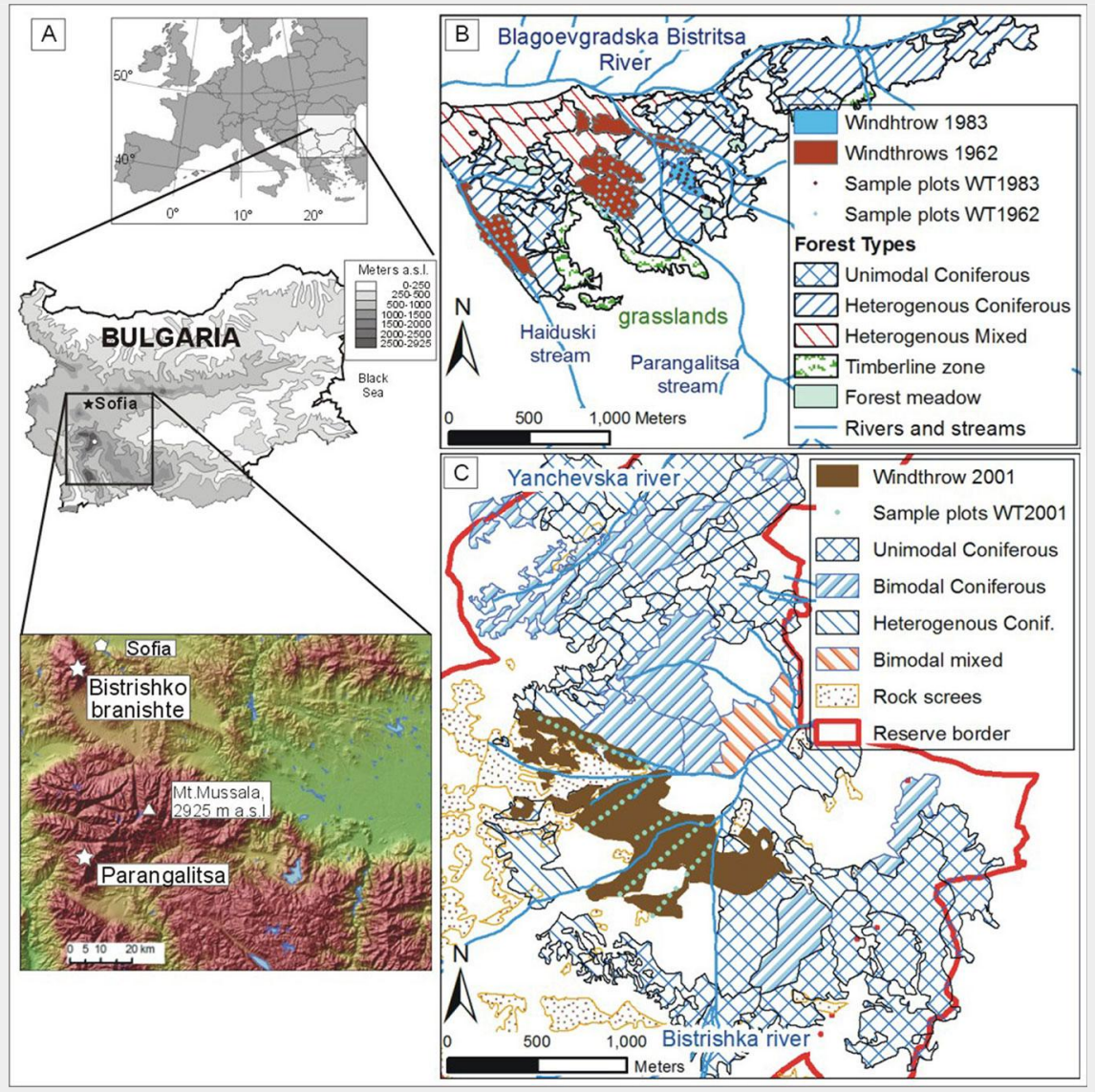

Fig. 1 - Location of the three investigated windthrow study areas in (B) Parangalitsa (WT-1962 and WT-1983) and (C) Bistrishko branishte (WT-2001). analyzed the natural regeneration following medium- and large-scale windthrows that occurred 10, 30 and 50 years ago in the Parangalitsa and the Bistrishko branishte Reserves in Bulgaria. Our specific study objectives were: (1) to examine the duration of the regeneration process in the blow-down areas; (2) to determine the temporal changes that occurred in species composition; and (3) to assess the suitability of different substrates for tree establishment.

\section{Materials and methods}

\section{Study sites}

We studied two subalpine Picea abies forests in Bulgaria, Southeastern Europe. The first site is situated in the Parangalitsa Forest Reserve within Rila National park $\left(42^{\circ} 05^{\prime} \mathrm{N}, 23^{\circ} 28^{\prime} \mathrm{E}\right)$, Southwestern Bulgaria (Fig. 1). The reserve was described as a primeval forest already by the first foresters who completed forest inventory measurements in the early 1930 s (Georgiev 1933). This was the main reason that it was declared as a strict reserve without management in 1933. The forest ( $250 \mathrm{ha}$ ) has developed without major human intervention for at least 200 years and was shaped by windthrows of various sizes (Panayotov et al. 2011a, 2015). It ranges from 1450 to $1950 \mathrm{~m}$ a.s.l. and is dominated by Norway spruce (Picea abies Karst.). At lower altitudes (below $1650 \mathrm{~m}$ a.s.l.) Norway spruce is mixed with up to $70 \%$ silver fir (Abies alba Mill.) and up to $40 \%$ European beech (Fagus sylvatica L.), while close to treeline Picea abies is mixed with up to $20 \%$ Macedonian pine (Pinus peuce Griseb.), a Balkan endemic species. Additionally, Scots pine ( $P$ inus sylvestris L.) co-dominates some of the forest patches with a heterogeneous structure on western exposures and ridges. Other tree species occurring in the site include rowan (Sorbus aucuparia L.), Salix caprea L., Betula pendula Roth and Populus tremula L. In 1962 and 1983, windthrows affected 22 and 4 ha, respectively, in Norway spruce-dominated forest patches over 150 years old. The 1962 windthrow was in several patches, the largest of which was 10 ha (Fig. 1). After the 1962 windthrow (hereafter referred to as WT-1962) most of the fallen logs were extracted, which is the only known large human intervention in the reserve, whereas the windthrow of 1983 (hereafter referred as WT-1983) was left uncleared.

The second selected study site is the Bistrishko branishte Forest Reserve within Vitosha Nature Park ( $\left.42^{\circ} 33^{\prime} \mathrm{N}, 23^{\circ} 18^{\prime} \mathrm{E}\right)$, situated above the city of Sofia (Fig. 1). The reserve was declared in 1934 to protect the last remnants of Norway spruce forests on Vitosha Mountain. Picea-dominated forests cover 650 ha at altitudes between 1400 and $1950 \mathrm{~m}$ a.s.l. In the lower parts (up to $1500 \mathrm{~m}$ a.s.l.) Norway spruce is mixed with European beech (Fagus sylvatica L.), Sycamore maple (Acer pseudoplatanus L.) and 
Balkan maple (Acer heldreichii Orph. ex Boiss.). Before the establishment of the reserve, the area was intensively logged until the 1850 s to feed locally-based metal ore production (Deliradev 1926). After the Crimean War (1853-1856) this industry became less profitable, which considerably decreased the logging pressure and allowed the forests in the core area of the reserve to start regenerating. Therefore, at the beginning of $21^{\text {st }}$ century the forests were predominantly homogeneous, even-aged stands not older than 140-150 years (Tsvetanov \& Panayotov 2013, Panayotov et al. 2015). In 2001 these forests were affected by a 60 ha windthrow (WT-2001), which was followed, starting in 2003 , by a massive bark beetle (Ips typographus L.) outbreak that killed the majority of the old Norway spruce trees over a 200 ha territory (Panayotov \& Georgiev 2012, Panayotov et al. 2015). The disturbed area was left to natural development without any human intervention.

The climate at both sites is typical for high mountain locations, with average annual temperatures of $+2.5^{\circ} \mathrm{C}$ at $1950 \mathrm{~m}$ a.s.l. in Parangalitsa Reserve (Panayotov et al. 2015) and $+2.3{ }^{\circ} \mathrm{C}$ at $1950 \mathrm{~m}$ a.s.l. in Bistrishko branishte Reserve (Tsvetanov \& Panayotov 2013). The annual precipitation amounts to $1055 \mathrm{~mm}$ at the first site and $1228 \mathrm{~mm}$ at the second, with a maximum in May-June and a minimum in August-September (Raev et al. 1987). The snow cover reaches $150 \mathrm{~cm}$ and lasts for more than 100 days. The bedrock is volcanic (granite in the Parangalitsa site, syenite and andesite in the Bistrishko branishte site). Soils are predominantly dark mountain soils (Mollic Cambisols) and brown mountain soils (Dystric and Umbric Cambisols) with sufficient depth. In some areas of Bistrishko branishte Reserve the soils lie on large spherical syenite blocks and therefore the rooting depth is limited. The herbaceous layer is dominated by Calamigrostis arundinacea (L.) Roth, Rubus ideaus L. and Vaccinium myrtillus L. (Pavlov et al. 1999). In both reserves the effect of browsing as a potential critical factor for tree regeneration (Reimoser et al. 1999, Newton 2007) was assessed as negligible because frequent sapling browsing has not been observed, the stock of ungulates in Bulgaria is low (Dachev et al. 2005) and large predators such as wolfs and bears are present.

\section{Sampling design and data collection}

The windthrow areas at both study sites were previously identified and mapped on the basis of forest maps and orthorectified digital aerial photographs in GIS using ArcGIS $^{\oplus}$ ver. 10 software (ESRI Inc., Redlands, CA, USA) by Panayotov et al. (2011a) and Panayotov \& Georgiev (2012). We established transects along altitudinal gradients in each windthrow area and set up $100 \mathrm{~m}^{2}$ sample plots $(10 \times 10 \mathrm{~m})$ every $50 \mathrm{~m}$. In total, we established 21 transects with 85 sample plots in the Parangalitsa Reserve, i.e., 16 transects with 71 plots in cleared windthrow WT-1962 and 5 transects with 14 sample plots in uncleared windthrow WT1983. In Bistrishko branishte Reserve we established 5 transects with 53 sample plots across the windthrow area. In 20122014, we examined the tree regeneration in each sample plot by recording the species composition, number, diameter at breast height (DBH), height and age of all individuals. Individuals with $\mathrm{DBH}<4 \mathrm{~cm}$ were recorded in eight height classes, excluding seedlings: $5-25 \mathrm{~cm} ; 25-50 \mathrm{~cm} ; 50-75$ $\mathrm{cm} ; 75-100 \mathrm{~cm} ; 101-125 \mathrm{~cm} ; 125-150 \mathrm{~cm} ; 150-$ $175 \mathrm{~cm}$; and $>175 \mathrm{~cm}$.

Because of the large size variation of the trees in the windthrow areas, we used two approaches to perform the age classification of the regeneration: (1) for individuals with $\mathrm{DBH}>4 \mathrm{~cm}$ (which were recorded as trees) we collected and analyzed 336 increment cores from heights of 0.3 to $0.5 \mathrm{~m}$; (2) for individuals with $\mathrm{DBH} \leq 4 \mathrm{~cm}$ (i.e., saplings) we constructed age-size models based on 732 cross-sections from 36 individuals of Picea abies, 23 individuals of Abies alba, 29 individuals of Fagus sylvatica and 34 individuals of Sorbus aucuparia (explained in detail in the next section). Owing to the protection status of the studied forests, the number of saplings used for the collection of cross-sections was limited. Because of the ecological similarity and hence initial growth of Norway spruce and Silver fir saplings, in the statistical analysis the cross-sections of these two species were combined. The cross-sections were obtained from heights of $0.0 \mathrm{~m}, 0.3 \mathrm{~m}, 0.5$ $\mathrm{m}, 1.0 \mathrm{~m}, 1.3 \mathrm{~m}$ and $2.0 \mathrm{~m}$. It is worth to note that such approaches of age determination make it possible to determine the age only of the above-ground stems. It is possible that some saplings were grazed and actually occurred in a prior period, which is often the case with deciduous species such as rowan (Danell et al. 2006, Bergquist et al. 2009). However, from the point of view of forest recovery and further dynamics, it is important to account for the development of stems with a height greater than $0.5 \mathrm{~m}$ because they have a greater chance of survival and display faster growth in the improved conditions after disturbances.

In addition, for sporadically registered pioneer species in the Bistrishko branishte Reserve (WT-2001), the period of germination was determined through whorl count- ing of the pine saplings (Pinus peuce Griseb. and Pinus sylvestris L. - Niklasson 2002, Zielonka 2006) and through examination of the length of annual stem growth, the presence of signs of post-disturbance release and the type of regeneration substrate (i.e., intact forest floor or disturbance-induced substrates such as pits, mounds and coarse woody debris) for the broadleaves. All saplings that showed signs of post-disturbance growth release, discerned by a drastic increase in the length of the annual stem growth, were classified as advance regeneration occurring prior to the wind disturbance of 2001, whereas saplings exhibiting constant vigorous annual growth from the ground level and growing on disturbance-induced substrates were classified as post-disturbance regeneration. Owing to the different approaches for age estimation and the lower survival probability of saplings, the results for trees and saplings are shown separately.

In order to analyze the influence of the regeneration substrates on the recruitment dynamics, we examined the distribution of saplings per microsite type (pit, mound, coarse woody debris and intact forest floor - hereafter (FF). The decomposition rate of coarse woody debris (CWD) was determined following the five classes of Hunter \& Schmiegelow (2011). The coverage of the main microsites types (Tab. 1) was estimated as a percentage, which was determined in each plot using 100 relevés with $1 \mathrm{~m}^{2}$ quadrates $(1 \times 1 \mathrm{~m})$.

\section{Sample processing and data analysis}

The collected increment cores and crosssections were sanded with progressively finer sand papers to ensure that the cells of tree rings were clearly identifiable. The cores were then scanned at 1200 dpi resolution with an Epson Expression $11000 \mathrm{XL}^{\oplus}$ scanner and measured with the software CooRecorder ver. 7.6 (Cybis Elektronik \& Data AB, Saltsjöbaden, Sweden). To ensure there were no missing rings and to determine the exact calendar year in which each tree ring was produced, we performed a crossdating procedure following standard methodology (Stokes \& Smiley 1996). We performed the crossdating with CDendro ver. 7.6 software (Cybis Elektronik \& Data $A B$ ), using regional reference chronologies for Picea abies (Panayotov et al. 2011b) and Abies alba (Panayotov M, unpublished) from our study sites. For the other species

Tab. 1 - Coverage of the regeneration substrate types in the sampled areas in 2015. (IFF): Intact forest floor; (CWD): coarse woody debris. (a): CWD was categorized into 5 decay states following Hunter \& Schmiegelow (2011).

\begin{tabular}{|c|c|c|c|c|c|c|c|c|c|}
\hline \multirow{3}{*}{ Disturbances } & \multicolumn{9}{|c|}{ Regeneration substrate (\%) } \\
\hline & \multirow{2}{*}{ IFF } & \multirow{2}{*}{ pit } & \multirow{2}{*}{ mound } & \multicolumn{5}{|c|}{ CWD, decomposition class ${ }^{(a)}$} & \multirow{2}{*}{$\begin{array}{l}\text { CWD } \\
\text { (all) }\end{array}$} \\
\hline & & & & 1 & 2 & 3 & 4 & 5 & \\
\hline Windthrow 1962 & 75.7 & 5.5 & 6.3 & 0 & 0.4 & 0.9 & 3.4 & 7.8 & 12.5 \\
\hline Windthrow 1983 & 68.9 & 5.4 & 6.1 & 0 & 0 & 2.2 & 7.7 & 9.7 & 19.6 \\
\hline Windthrow 2001 & 75.2 & 4 & 4.4 & 0 & 16.3 & 0 & 0 & 0.1 & 16.4 \\
\hline
\end{tabular}


we built site-level tree-ring chronologies using cores from the sites. We used the data obtained from the cross sections to develop age-height relationship equations for the saplings with $\mathrm{DBH} \leq 4 \mathrm{~cm}$. We followed the approach of Rohner et al. (2013) and tested twelve growth models (polynomial approach) to determine the number of years it took the saplings to reach a certain height. We considered first- to third-order polynomials for describing the relationship between sapling height and age. All polynomials were fitted to the ages and heights of the model trees in the year of coring (2012-2014). We selected the best performing model based on the highest $R^{2}$ and the lowest mean absolute error (MAE) and root mean squared error (RMSE). The estimated ages of the sampled trees and the modeled age of saplings were grouped into age classes of 15 years distributed along a time scale with respect to the dates of the wind disturbances. We chose 15-year classes to ensure that the modeled age of the small-sized saplings plus the expected error (i.e., up to 5 years) would fit into the classes.

The normality of the regeneration distributions was checked by Shapiro-Wilk tests, which showed that all the data deviated significantly from the normal distribution. We therefore used Wilcoxon Signed Rank tests to check for significant changes in the average numbers of the regeneration on specific regeneration substrates for different periods after the disturbances.

\section{Results}

\section{Age distribution of the regeneration}

The age distribution of the trees and saplings registered in the sample plots in the 1962, 1983 and 2001 windthrow areas showed that most of them recruited after the disturbances (Fig. 2). The best-performing equation for the Norway spruce and sil-

a) Parangalitsa 1962 cleared windthrow
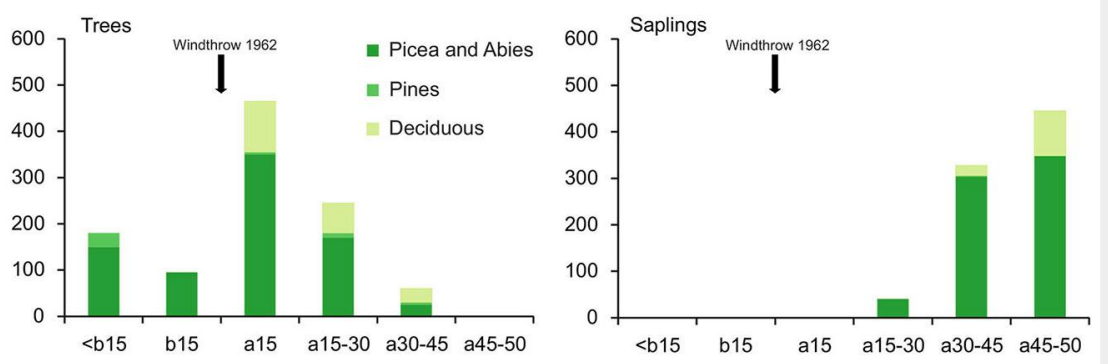

b) Parangalitsa 1983 uncleared windthrow
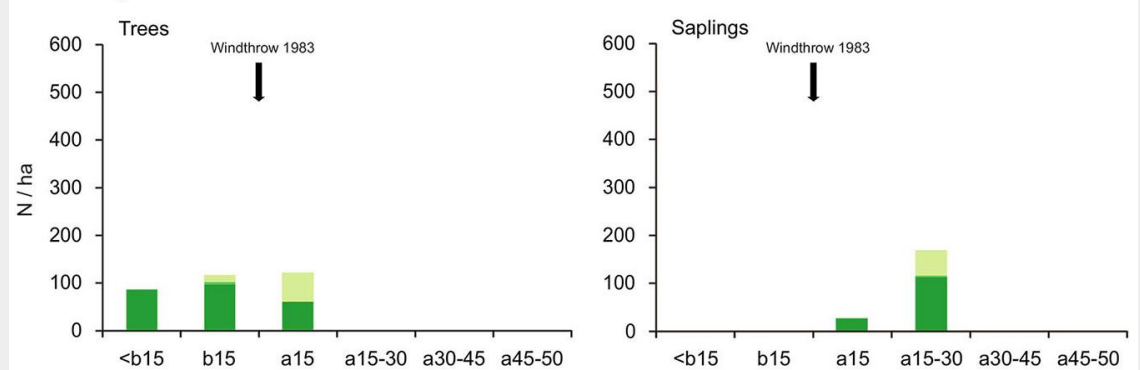

c) Bistrishko branishte 2001 uncleared windthrow
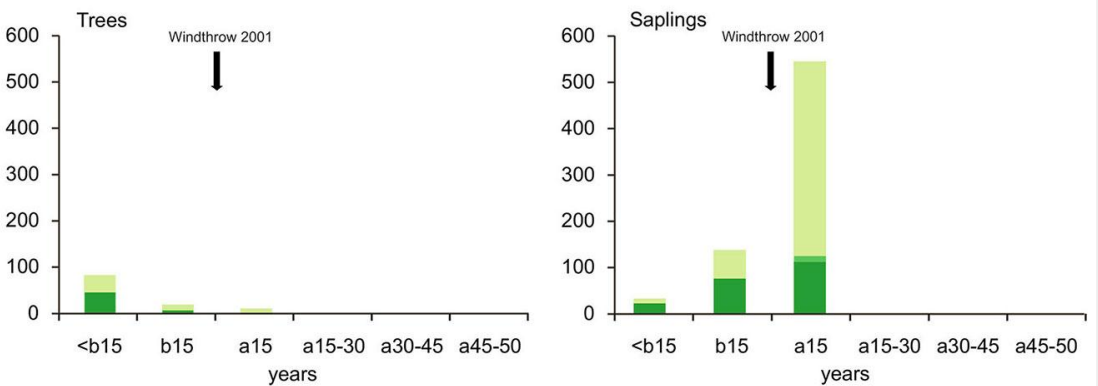

Fig. 2 - Regeneration distribution by 15 -year periods of trees (DBH $>4 \mathrm{~cm}$ ) and saplings $(\mathrm{DBH} \leq 4 \mathrm{~cm}$ ) in the Parangalitsa and the Bistrishko branishte Reserves for: (a) the 1962 windthrow; (b) the 1983 windthrow; and (c) the 2001 windthrow. Vertical arrows indicate the years of the windthrow events. Abbreviations: (b15): 15 years before the windthrow; (a15, a15-30, etc.): 15 years after the windthrow, 15-30 years after the windthrow, etc.; (Picea \& Abies): Picea abies Karst. and Abies alba Mill.; (Pines): Pinus sylvestris L. and Pinus peuce Grisebach; (Deciduous): Sorbus aucuparia L., Fagus sylvatica L., Salix caprea L., Betula pendula Roth, Populus tremula L., Acer heldreichii Orph. ex Boiss, and Acer pseudoplatanus L. ver fir saplings was Age $=15.72 \cdot H^{0.63}\left(R^{2}=\right.$ 0.917 ; $M A E=0.501 ;$ RMSE $=0.796)$; for rowan it was Age $=2.33 \cdot H^{0.89}\left(R^{2}=0.966\right.$; $M A E=0.237 ;$ RMSE $=0.281$ ) and for European beech it was Age $=1.30 \cdot \mathrm{H}+7.44 \cdot \mathrm{H}^{2}$ $3.76 \cdot H^{3}\left(R^{2}=0.906 ; \mathrm{MAE}=0.117 ; \mathrm{RMSE}=\right.$ $0.133)$. The equations were fitted with data from $70 \%$ of the tree-discs, while the other $30 \%$ were used for verification. The age estimation errors at $95 \%$ from the verification samples were up to 5 years for Norway spruce and silver fir; 2 years for rowan, and 4 years for European beech. The tested DBH-Age equations for trees with $\mathrm{DBH}>4$ $\mathrm{cm}$ did not provide the desired accuracy and thus we analyzed the age structure based solely on the trees from which we had increment cores. They were about $20 \%$ of all trees with $\mathrm{DBH}>4 \mathrm{~cm}$ in the Parangalitsa site and were relatively equally distributed across the available DBH classes. Because the cores were collected at a height of 0.3 to $0.5 \mathrm{~m}$, we applied a correction to the establishment age based on the average time of growth of saplings from the ground surface to the coring height (7 years for $0.3 \mathrm{~m}$ height and 11 years for 0.5 $\mathrm{m}$ height for Norway spruce and silver fir; 2 years for $0.3 \mathrm{~m}$ and 4 years for $0.5 \mathrm{~m}$ height for rowan) obtained from the analysis of stem discs.

In WT-1962 the advance regeneration (i.e., trees established before the date of the windthrow, mainly Picea abies and Abies alba) was about 270 indiv. ha- ${ }^{-1}$ in total, while the post-disturbance regeneration formed by trees and saplings, which developed during the first 30 years after the windthrow (referred to as "initial postdisturbance regeneration"), amounted to about 750 indiv. ha ${ }^{-1}$ (Fig. 2a). However, 30 years after the windthrow there was a noticeable increase in the regeneration numbers, which amounted to another 833 indiv. ha' (referred to as "secondary postdisturbance regeneration"). In WT-1983 the advance regeneration of Picea abies and Sorbus aucuparia, formed in the decades preceding the disturbance, amounted to around 200 indiv. ha ${ }^{-1}$ (Fig. 2b). In this windthrow area the initial post-disturbance regeneration was formed mainly during the first 15 years after the disturbance and amounted to approximately 100 indiv. ha- ${ }^{-1}$. In the 15 to 30 years after the disturbance the recruitment numbers doubled to more than 300 indiv. ha" (Fig. 2b), which was classified as "secondary post-disturbance regeneration". For the windthrow in Bistrishko branishte Reserve (WT-2001), the regeneration density was estimated to be 816 indiv. ha ${ }^{-1}$. The post-disturbance regeneration was 552 indiv. ha ${ }^{-1}$ (Fig. 2C), while the advance regeneration was less than half this value (264 indiv. ha ${ }^{-1}$.

\section{Species composition of regeneration}

In all studied windthrow areas Picea abies and Sorbus aucuparia were the dominating regeneration species. However, there were some differences related to the participa- 
tion of pioneer species and the contribution of Sorbus aucuparia (Fig. 3).

In the cleared windthrow of 1962 in Parangalitsa Reserve (WT-1962) Norway spruce dominated the advance regeneration, as well as the initial and the secondary post-disturbance regeneration (64\%, 62\% and $51 \%$, respectively), followed by silver fir (relevés 31\%, $11 \%$ and 33\%, respectively - Fig. 3a). The participation of rowan in the advance regeneration was low (up to $2 \%$ of all saplings and trees) and increased slightly in the initial and the secondary post-disturbance regeneration ( $7 \%$ and $11 \%$, respectively). Pioneer species from the genera Salix, Betula and Pinus played a smaller role, contributing less than $15 \%$ in total, and occurred mostly in the first decades after the disturbance.

In the uncleared windthrow of 1983 in Parangalitsa Reserve (WT-1983) the advance regeneration and the post-disturbance regeneration were dominated by Picea abies (46\% and 64\%, respectively) and Sorbus aucuparia (28\% and $26 \%$, respectively). In the group of the most recently occurring saplings (i.e., 15-30 years after the windthrow), the difference between the two species increased but was still not significant.

The participation of the pioneer species Betula pendula, Salix caprea, Pinus sylvestris and Pinus peuce in WT-1983 decreased slightly between the initial post-disturbance regeneration and the more recently occurring one (from $10 \%$ to $7 \%$ ).

In the uncleared windthrow area in Bistrishko branishte Reserve (WE-2001) the post-disturbance regeneration was dominated by broadleaved species, which accounted for $70 \%$ of all saplings and trees in this age group - mainly Sorbus aucuparia (32\%), Fagus sylvatica (21\%), Salix caprea (8\%) and Populus tremula (6\%), while the advance regeneration was dominated by Picea abies (51\%), followed by Sorbus aucuparia (27\%) and Fagus sylvatica (16\%).

\section{Regeneration substrate}

In terms of spatial distribution, the main regeneration substrate for the initial postdisturbance regeneration in the three studied areas was the intact forest floor (IFF), which hosted between 69 and $80 \%$ of the regeneration (Fig. 4a). This value corresponded with its total cover area, which varied between 69 and $76 \%$ (Tab. 1). In the secondary post-disturbance regeneration (Fig. 4b), occurring 15-30 years after the windthrows, the importance of the coarse woody debris (CWD) for the regeneration rose significantly in comparison to the initial post-disturbance regeneration and supported $49 \%$ of the regeneration in WT-1983 (Wilcoxon Signed Ranked test, $\mathrm{p}<0.001$ ) and $41 \%$ in WT-1962 ( $\mathrm{p}<0.001)$, while IFF hosted $48 \%$ and $32 \%$ of the regeneration, respectively. Despite its low cover of only up to $20 \%$, CWD proved to be a particularly suitable substrate for the recruitment of Picea abies and Abies alba, accounting for a) Parangalitsa 1962 windthrow, cleared

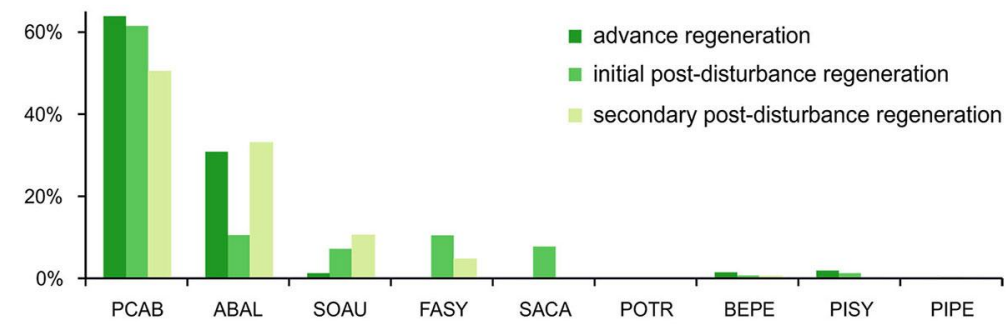

b) Parangalitsa 1983 windthrow, uncleared

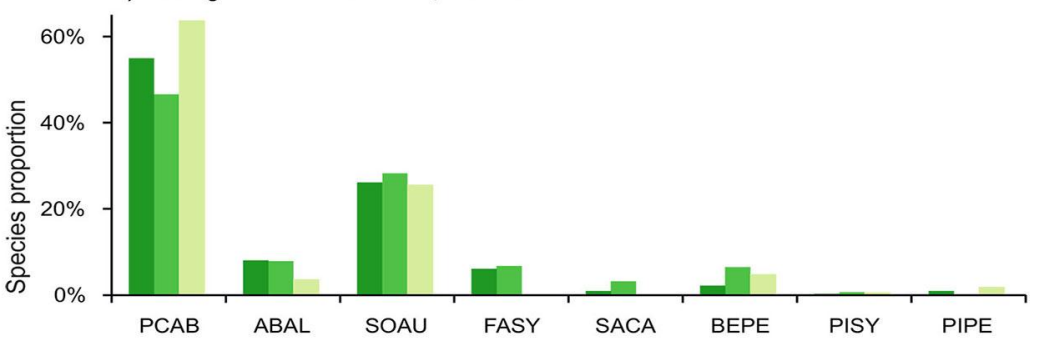

C) Bistrishko branishte 2001 windthrow, uncleared

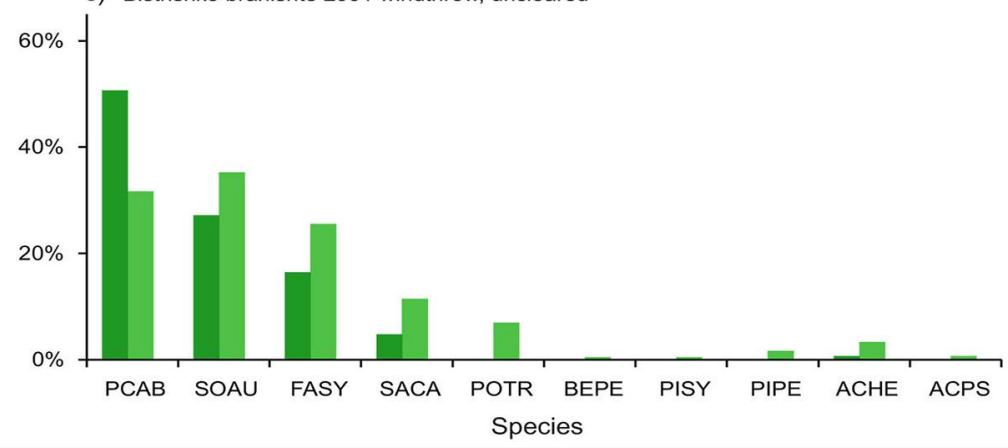

Fig. 3 - Species proportions between advance regeneration, initial post-disturbance regeneration and secondary post-disturbance regeneration: (a) 1962 windthrow; (b) 1983 windthrow; and (c) 2001 windthrow. (PCAB): Picea abies; (ABAL): Abies alba; (SOAU): Sorbus aucuparia; (FASY): Fagus sylvatica; (PISY): Pinus sylvestris; (PIPE): Pinus peuce; (SACA): Salix caprea; (BEPE): Betula pendula; (POTR): Populus tremula; (ACHE): Acer heldreichii; (ACPS): Acer pseudoplatanus.

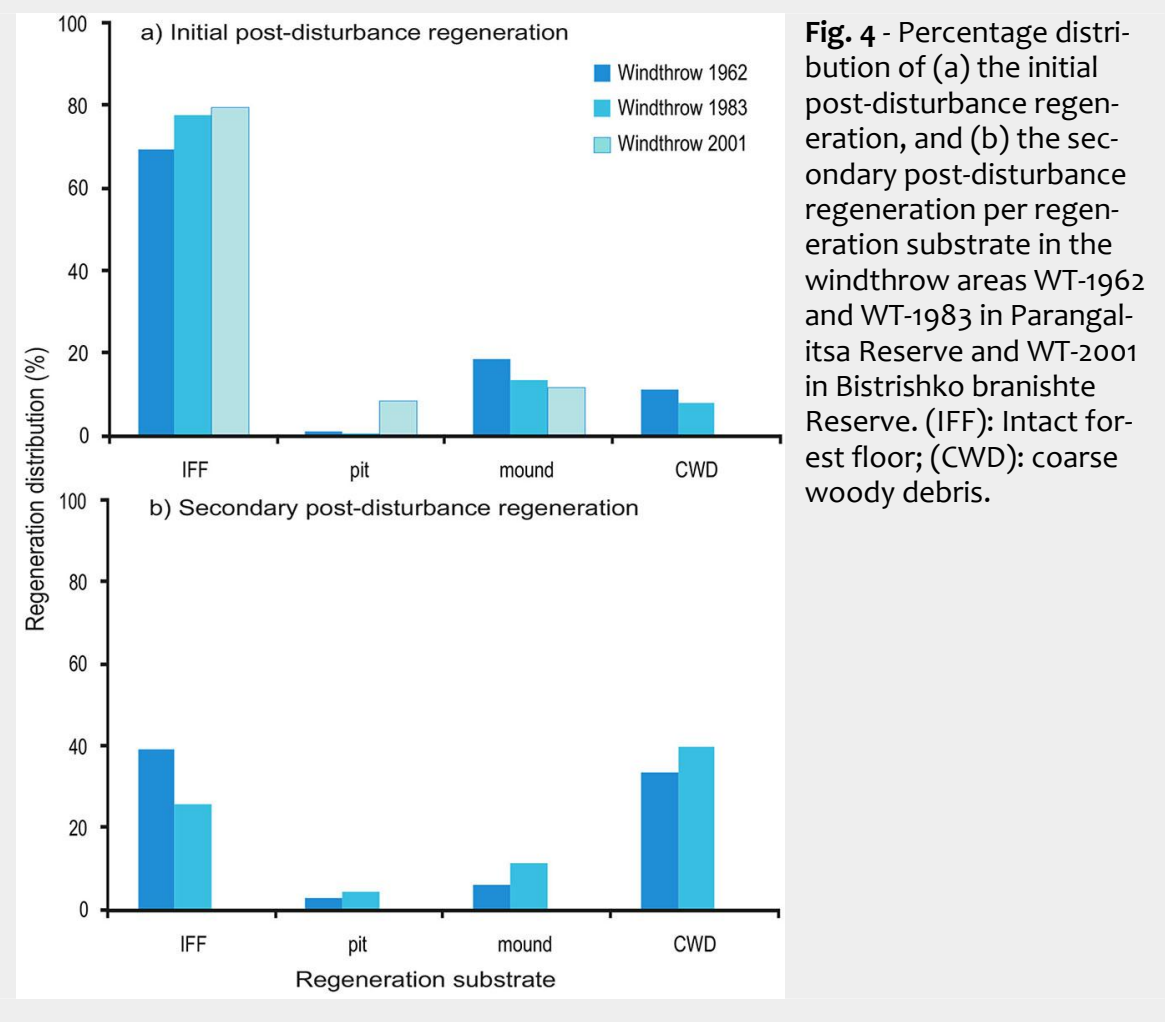




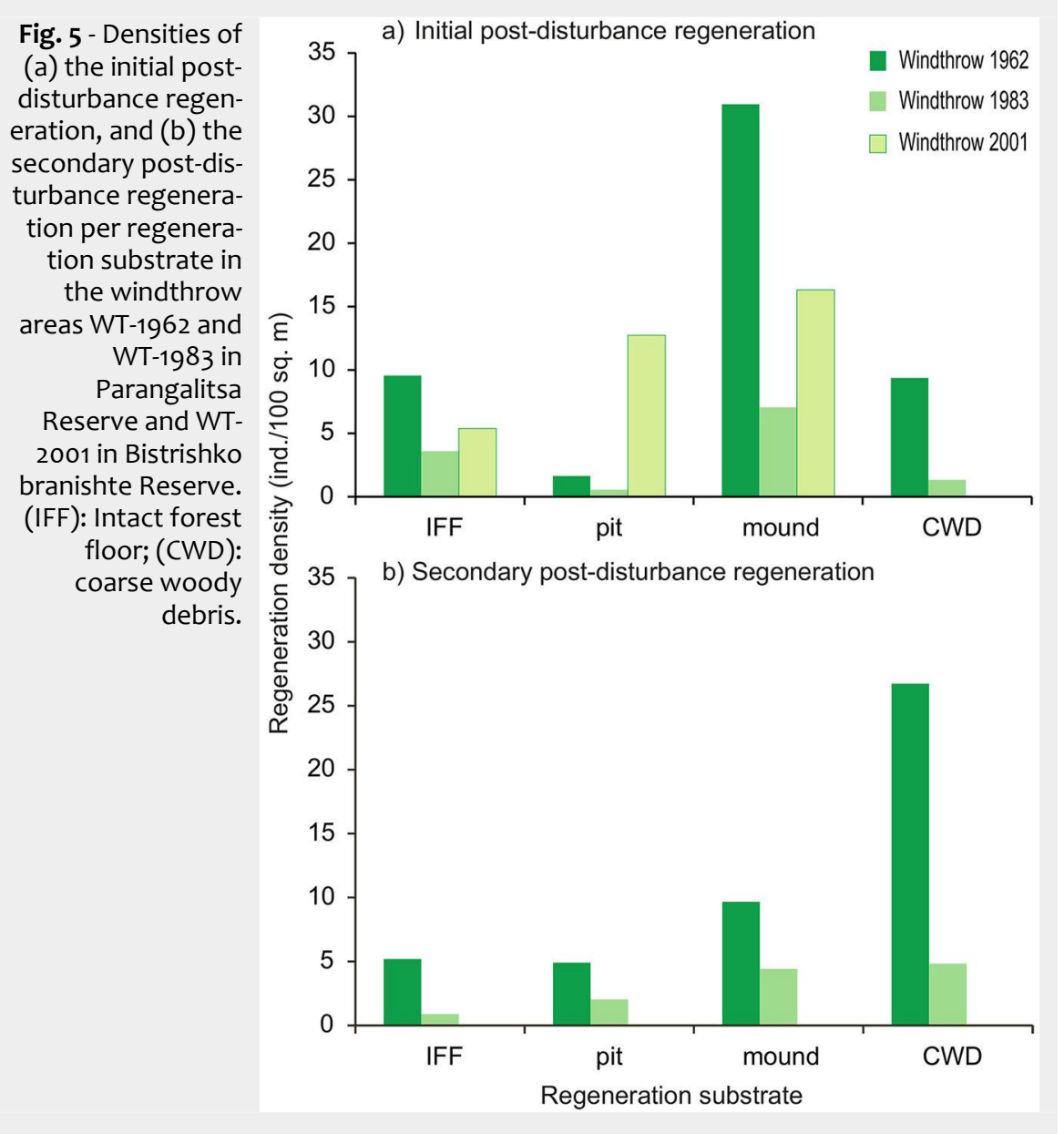

$80 \%$ of the regeneration of these two species. The proportion of the regeneration on pits and mounds remained under $20 \%$ of the total regeneration for both the initial and the secondary regeneration (Fig. 4).

In terms of regeneration density, i.e., regardless of the area that a specific substrate covers, the highest value for the initial post-disturbance regeneration was observed on pits and mounds (30 indiv. 100 $\mathrm{m}^{-2}$ - Fig. 5), while for the secondary regeneration the highest regeneration density was found on coarse woody debris (27 indiv. $100 \mathrm{~m}^{-2}$ ). Despite having the largest cover area (Tab. 1), IFF was characterized by the lowest regeneration densities, remaining under 10 indiv. $100 \mathrm{~m}^{-2}$ for both the initial and the secondary post-disturbance regeneration.

\section{Discussion}

Age distribution of the regeneration

Our results describe the long- and shortterm regeneration of forest recovery about 10,30 and 50 years after stand-replacing wind disturbances in two unmanaged subalpine spruce forests in Southeastern Europe, Parangalitsa and Bistrishko branishte Reserves.

In line with the results of Svoboda et al. (2010), Panayotov et al. (2011a) and Holeksa et al. (2012), we found that the stand reinitiation phase (after Oliver 1981) can last for more than 30-50 years after standreplacing wind disturbances in subalpine forests.

Our results further highlight that, in a period of several decades, the forest recovery of the studied windthrow areas was characterized by initially high regeneration, folcrease in regeneration about 30-50 years after the disturbance. We perceived these fluctuations as regeneration waves; they were more clearly expressed in the windthrow that occurred more than 50 years ago (WT-1962) but also already appeared in the windthrow that occurred 30 years ago (WT-1983).

The advance regeneration was less numerous than the post-disturbance regeneration in all investigated windthrow areas. Well-established trees with $\mathrm{DBH}>4 \mathrm{~cm}$ were most numerous in the windthrows that occurred in older (age above $>150$ years prior to the windthrow - Panayotov et al. 2015) forests of Parangalitsa Reserve. The initial post-disturbance regeneration was lowest in the uncleared windthrow in old-growth forest (WT-1983), which is in line with the findings of other studies (Wohlgemuth et al. 2002, Moćalov \& Lässig 2002, Jonášová et al. 2010). We note that, because of the long time span after the older disturbances in Parangalitsa reserve (30 to 50 years), a fraction of the initial lowed by a decrease and then a new in- post-disturbance regeneration had probably already died and the initial densities were most likely higher.

The initial larger post-disturbance regeneration and the gradual decrease in numbers in the following decades can be explained by several factors. Immediately after the windthrow events, open spaces provide suitable light conditions for regeneration. However, these spaces are quickly occupied by grass and shrub species from genera such as Rubus, Calamigrostis, Luzula, Epilobium and Vaccinium, which hinders the regeneration of Norway spruce and silver fir (Dimitrov 1999, Jehl 2001, Fischer et al. 2002, Wohlgemuth et al. 2002, Keidel et al. 2008, Heurich 2009, Jonášová et al. 2010, Vodde et al. 2010). In this respect, the low recruitment densities (i.e., less than 500 indiv. $\mathrm{ha}^{-1}$ ) observed for the first decades (Fig. 2) were in line with other findings. The post-disturbance regeneration in the uncleared windthrow areas reached a first peak during the first 15 years after the disturbances. The number of Picea saplings (about 100 indiv. ha ${ }^{-1}$ ) was particularly low in the large windthrow area in Bistrishko branishte Reserve. This was probably the combined result of several factors: (i) the limited seed source due to the large size of the disturbed area (6o ha); (ii) the almost complete lack of surviving old seedling trees, due to the high intensity of the storm and probably to the former forest structure, which was homogeneous with almost a complete lack of smaller-sized trees (Panayotov et al. 2015); and (iii) the rapid large-scale mortality of mature spruce trees at the windthrow borders as result of the severe bark beetle outbreak following the wind disturbance (Panayotov \& Georgiev 2012). Seed dispersal in Picea abies is performed mostly by wind and is confined to short distances (up to about $100 \mathrm{~m}$ ) from the trees (Lässig et al. 1995). In addition, the windthrow area in Bistrishko branishte Reserve was quickly occupied by dense raspberry (Rubus idaeus L.) communities, which covered up to $60 \%$ of the total area in the analyzed plots. In comparison, the first regeneration wave in the cleared windthrow area of 1962 in Parangalitsa Reserve lasted for three decades, presumably as a result of the longer availability of suitable regeneration substrates in the harvested terrain there. The results from the study site in Parangalitsa demonstrate that if the initial regeneration wave was not able to create a stand with a high density, a secondary regeneration can occur several decades later (in our case after about 30 years). This second regeneration wave was most likely associated with an improvement in the regeneration conditions 30 to 40 years after the windthrow, namely an increasing decomposition stage of the available coarse woody debris (Veblen 1992, Ulanova 2000, Zielonka 2006) as well as an enhanced regeneration capacity and an improved sheltering function of the young forest, which developed as a result 
of the growth of the advance regeneration and the initial post-disturbance regeneration in the first decades after the distur bance.

Further, our results support the finding of numerous studies that the released advance regeneration may be small in the short term but can play a decisive role in the recovery of disturbed spruce forests (Wohlgemuth et al. 2002, Schönenberger 2002, Kulakowski \& Veblen 2003, Heurich 2009, Jonášová et al. 2010). For instance, in the first 15 years after the disturbances in the uncleared windthrow areas of 1983 and 2001, the advance regeneration of Picea abies was still greater than the number of newly established spruce saplings. Further, the surviving trees in the advance regeneration may play an increasingly important role in the next stages of forest recovery, which is discussed below.

\section{Species composition}

Our results show that the species composition of the regeneration in the three windthrow areas was quite similar. In line with findings from other studies (Jehl 2001, Wohlgemuth et al. 2002, Keidel et al. 2008, Jonášová et al. 2010), we found that the wind disturbances created suitable conditions for re-establishment of the dominant species in the intact stands before the disturbances - Picea abies, Abies alba and Sorbus aucuparia in the Parangalitsa forest, and Picea abies and Sorbus aucuparia in the Bistrishko branishte forest. An exception was the limited participation of Sorbus aucuparia in the cleared windthrow area of 1962. Given the fact that the age of the forests affected by the 1962 and 1983 windthrows was similar, i.e., more than 150 years old (Panayotov et al. 2015), there was probably advance regeneration of rowan in the windthrow area formed in 1962 that was later damaged during the salvage logging operation. In that period wood extraction was done with the assistance of animals (oxen), which could have damaged rowan by grazing and trampling. We note that Sorbus aucuparia has an ecological position between pioneer and climax species (Fischer et al. 2002) and, as a result of its long-term survival in the seedling bank, has often been recorded as the first tree species to colonize canopy gaps (Zywiec \& Ledwon 2008) and as a temporary co-dominant species the regeneration process, together with Picea abies (Siegrist 2000, Heurich 2009). Nonetheless, over the long term the presence of rowan in the stand declines because of its relatively short lifespan, and Picea abies therefore usually becomes the sole dominant species.

The occurrence of pioneer species was less than expected overall and more pronounced in the first stages of the post-disturbance regeneration process. Although large-scale disturbances often lead to a considerable increase in the proportion of pioneer species (Siegrist 2000, Moćalov \& Lässig 2002, llisson \& Chen 2009, Vodde et al. 2010), their occurrence was sporadic in two of our study areas (WT1962 and WT1983 in Parangalitsa Reserve). In the site with the largest and most recent windthrow (WT2001), where the contribution of broadleaf species in the regeneration was higher, typical pioneers such as Salix caprea and Populus tremula were more frequent but still less numerous than Fagus sylvatica and Sorbus aucuparia. In the cleared windthrow area of 1962, where the disturbed soil cover after the salvage logging was expected to promote seed germination of pioneer species (Schönenberger \& Wasem 1999, Fischer et al. 2002, Jonášová et al. 2010), the participation of Picea abies was still more than $70 \%$. The dominance of Picea abies in the regeneration process can be explained by the harsher climate conditions in the subalpine zone, which are less favorable for broadleaf species. In addition, the fragmentation of the windthrow areas into patches of less than 10-15 ha in Parangalitsa site promoted the short-distance seed dispersal of Picea abies (Lässig et al. 1995). At the same time, the presence of seeding pioneer trees was limited in the intact forest stands. Indeed, in forests where pioneer species were found to dominate the post-windthrow regeneration, the participation of these species was already relatively high before the disturbances (Fischer et al. 2002, Moćalov \& Lässig 2002, Wohlgemuth et al. 2002).

The secondary regeneration occurring in later decades after the disturbance (i.e., 30-40 years later) was dominated by the dominant species, with highest participation for Picea abies, Abies alba, Sorbus aucuparia and Fagus sylvatica. Especially silver fir strongly increased its presence in the windthrow area formed in 1962 (Fig. 3). Several factors may be associated with the observed regeneration pattern. On the one hand, probably the most important factor was the increase in height and maturation of trees from the advance regeneration, which facilitated seedling dispersal (and decreased the suppressive role of the grass layer) and provided shelter for the newly established saplings. In Parangalitsa Reserve the advance regeneration was frequently composed of trees with a large $\mathrm{DBH}$; at the time of sampling, these trees already had a DBH $>32 \mathrm{~cm}$ and an age of about 60 years for the 1962 windthrow, and a $\mathrm{DBH}>28 \mathrm{~cm}$ and an age $>40$ years for the 1983 windthrow. This is related to the fact that the disturbed forest was more than 150 years old and the regeneration processes had already started. Trees that established immediately after the disturbance also reached ages old enough (i.e., more than 20-30 years) to be able to provide shelter and start to regenerate (Tjoelker et al. 2007). On the other hand, the species composition of the secondary postdisturbance regeneration was at least partly associated with changes in the proportion of available regeneration substrates (discussed further), of which CWD particu- larly assists spruce regeneration. In addition, shading by the crowns of trees decreased the proportion of grass-covered substrates. Spruce, fir and beech benefit from the reduction of grass coverage and, at the same time, can successfully regenerate in shadow or mixed shade conditions (Stancioiu \& O’Hara 2006).

\section{Regeneration substrate}

The observed changes in the regeneration patterns can partly be explained by the spatial distribution and the changes in the suitable regeneration substrates in the course of the recruitment process. After large-scale wind disturbances, an increase in the area of micro-relief forms such as CWD, pits and mounds is observed (Ulanova 2000). Regeneration is often concentrated on these forms because they provide suitable regeneration substrate free of ground vegetation for a longer period (Jehl 2001, Kuuluvainen \& Kalmari 2003, Keidel et al. 2008). Our data show that shortly after the wind disturbances IFF, pits and mounds were particularly important for the initial post-disturbance regeneration. Their importance quickly decreased over time, however, mainly because they were covered by Calamigrostis arundinacea and Rubus idaeus, which are perceived as highly suppressive for the establishment and growth of saplings (Fischer et al. 2002, Keidel et al. 2008, Holeksa et al. 2012).

In particular, our results confirm the importance of deadwood for the successful competitive ability of spruce and fir saplings (Jehl 2001, Kuuluvainen et al. 2002, Motta et al. 2006, Zielonka 2006, Svoboda et al. 2010). Initially, only a small proportion of the post-disturbance regeneration in the study sites developed on CWD, because most of the CWD had still not reached the more advanced stages of decomposition, which are suitable for sapling development (Zielonka 2006). Still, we do not exclude the possibility that part of the regeneration we observed on IFF was actually established on CWD that was no longer distinguishable, especially in the site where the windthrow occurred more than 50 years ago. Twenty to thirty years after the wind disturbances in the Parangalitsa site, however, the CWD from the windblown trees had already reached the third or fourth class of decomposition, which made it a suitable substrate for regeneration (Holeksa 2001, Zielonka 2006, Holeksa et al. 2008). We found that within this period the regeneration densities on CWD tripled and were highest in the oldest windthrow site where the CWD had reached more advanced classes of decomposition (Tab. 1). As a result, nearly half of the newly established saplings in the secondary regeneration were found on CWD. Even though the deadwood was collected immediately after the 1962 windthrow, subsequent mortality of single surviving trees and trees at the borders of the windthrow areas created the opportunity for the presence of this 
substrate 50 years later. In our opinion, besides enhancing the regeneration capacity and sheltering functions of the first regeneration cohort, the progressive decay of deadwood gave rise to a second wave of post-disturbance regeneration. In this respect, we expect that the importance of CWD as a regeneration substrate for Picea abies in the windthrow of 2001 will increase significantly as long as the blown-down logs are sufficiently decayed (Keidel et al. 2008) and the initial regeneration trees grow enough to start producing seeds and providing shelter. In addition, the wood decayed by mycorrhizal fungi can provide a larger supply of $\mathrm{Ca}, \mathrm{Mg}$ and $\mathrm{K}$ cations, which are important for seedling establishment and growth (Ostrofsky et al. 1997).

\section{Conclusions}

Our study covered up to 50 years of natural forest recovery after stand-replacing wind disturbances, allowing to describe and analyze the short- and long-term forest recovery in two mountain Norway spruce forests in Southeastern Europe. Our data confirm previous findings that forest recovery after medium- and large-scale wind disturbances may be a long-lasting and dynamic process. In particular, we observed two discrete peaks of post-disturbance regeneration, reflecting the changes in the availability of suitable regeneration substrates, as well as the enhanced regeneration capacity and sheltering functions of the young forest. As a result, 30-50 years after the disturbances the regeneration processes were continuing in locations where the forest canopy was still not completely closed. In both study areas the windthrows led to reestablishment of Picea abies and other species that were dominant in the studied forests before the disturbances. The occurrence of pioneer species was limited to the very first stages of the regeneration process. The most important regeneration substrates were intact forest floor in the first decades after the disturbances and coarse woody debris three to four decades later. Our data demonstrate that the resilience of subalpine spruce forests against natural disturbances in terms of regeneration capacity largely depends on the presence of advance regeneration and appropriate regeneration substrates, such as dead wood in advanced decomposition stages. These findings are highly relevant for the concept of sustainable management of mountain Norway spruce forests, both in managed and protected areas, because they suggest that the silvicultural management systems in such forests should guarantee sufficient amounts of advance regeneration and CWD.

\section{Acknowledgements}

This research was supported by the Swiss Enlargement Contribution in the framework of the Bulgarian-Swiss Research Programme, project IZEBZO_143109 and proj- ect No. DMU 02/22/2009 of the Ministry of Science and Education of Bulgaria. The work was supported by grant no. BG05 M2OP001-2.009-0034-C01, financed by the Science and Education for Smart Growth Operational Program (2014-2020) and co-financed by the EU through the ESIF. We are grateful to Toma Tonchev for valuable comments and advice for statistical modeling and Anita Kostadinova, Velislava Shishkova, Suzana Takova, Simona Sokolova and Neli Nikolova for assistance with fieldwork. We thank Melissa Dawes for providing linguistic suggestions on the manuscript. We are grateful to two anonymous reviewers for their valuable comments on a previous version of the manuscript. We express our gratitude to the Ministry of Environment and Waters of Bulgaria for permission to work in Parangalitsa and Bistrishko branishte Biosphere Reserves and the office of Rila National Park for local assistance.

\section{References}

Attiwill PM (1994). The disturbance of forest ecosystems: the ecological basis for conservative management. Forest Ecology and Management 63: 247-300. - doi: 10.1016/0378-1127(94) 90114-7

Bebi P, Kulakowski D, Rixen C (2009). Snow avalanche disturbances in forest ecosystems state of research and implications for management. Forest Ecology and Management 257: 1883-1892. - doi: 10.1016/j.foreco.2009.01.050

Bergquist J, Löf M, Orlander G (2009). Effects of roe deer browsing and site preparation on performance of planted broadleaved and conifer seedlings when using temporary fences. Scandinavian Journal of Forest Research 24: 308317. - doi: $10.1080 / 02827580903117420$

Brang $P$, Schönenberger W, Frehner $M$, Schwitter R, Thormann JJ, Wasser B (2006). Management of protection forests in the European Alps: an overview. Forest Snow and Landscape Research 80: 23-44.

Dachev B, Genov P, Dutsov A, Nikolova S, Petrov I, Vasilev V (2005). Distribution, number and use of ungulates in Bulgaria. Forest Science 3: 89-107. [in Bulgarian]

Danell K, Duncan P, Bergström R, Pastor J (2006). Large herbivore ecology, ecosystems dynamics and conservation. Cambridge University Press Inc., Cambridge, UK, pp. 524. [ISBN 978-0-511-21964-1]

Dale VH, Joyce LA, McNulty S, Neilson RP, Ayres $M P$, Flannigan MD, Hanson PJ, Irland LC, Lugo $A E$, Peterson CJ, Simberloff D, Swanson FJ, Stocks BJ, Wotton BM (2001). Climate change and forest disturbances. BioScience 51: 723-734. doi: 10.1641/0006-3568(2001)051[0723:CCAFD] 2.o.CO;2

Deliradev P (1926). Vitosha. Gladstone Press, Sofia, Bulgaria, pp. 344. [in Bulgarian]

Dimitrov M (1999). Succession process of vegetation in windthrow area in association PiceetoAbietum luzulosum, Yundola Training and Experimental Forest Range. Forestry Idea 1: 13-27. [in Bulgarian]

Donato DC, Harvey BJ, Turner MG (2016). Regeneration of montane forests 24 years after the 1988 Yellowstone fires: a fire-catalyzed shift in lower treelines? Ecosphere 7(8): e01410. - doi: 10.1002/ecs2.1410

Fischer A, Lindner M, Abs C, Lasch P (2002). Vegetation dynamics in Central European forest ecosystems (near-natural as well as managed) after storm events. Folia Geobotanica 37: 17-32. - doi: $10.1007 / B F 02803188$

Georgiev Z (1933). Parangalitsa. Forestry Ideas 2: 16-32. [in Bulgarian]

Heurich M (2009). Progress of forest regeneration after a large-scale Ips typographus outbreak in the subalpine Picea abies forests of the Bavarian Forest National Park. Silva Gabreta 15: 49-66.

Holeksa J (2001). Coarse woody debris in a Carpathian subalpine spruce forest. Forstwissenschaftliches Centralblatt 120: 256-270. - doi: 10.1007/BF02796097

Holeksa J, Zielonka T, Zywiec M (2008). Modeling the decay of coarse woody debris in a subalpine Norway spruce forest of the West Carpathians, Poland. Canadian Journal of Forest Research 38: 415-428. - doi: 10.1139/X07-139

Holeksa J, Zielonka T, Zywiec M (2012). Norway spruce Picea abies regeneration and canopy disturbance in a carpathian subalpine forest. In: "Spruce: Ecology, Management and Conservation" (Nowak KI, Strybel HF eds). Nova Science Publishers, Inc., New York, USA, pp. 1-40. [ISBN 978-1-61942-494-4] [online] URL: http://www. researchgate.net/publication/233756191

Hunter ML, Schmiegelow FKA (2011). Wildlife, forests and forestry: principles of managing forests for biological diversity $\left(2^{\text {nd }}\right.$ edn). Prentice Hall, Upper Saddle River, New Jersey, USA. pp. 259. [ISBN 978-0-13-501432-5]

Ilisson T, Chen HYH (2009). Direct regeneration hypothesis in northern forests. Journal of Vegetation Science 20: 735-744. - doi: 10.1111/j.16541103.2009.01066.x

Jonášová M, Prach K (2004). Central-European mountain spruce (Picea abies (L.) Karst.) forest: regeneration of tree species after a bark beetle outbreak. Ecological Engineering 23: 15-24. doi: 10.1016/j.ecoleng.2004.06.010

Jonášová M, Vávrová E, Cudlin P (2010). Western Carpathian mountain spruce forest after a windthrow: natural regeneration in cleared and uncleared areas. Forest Ecology and Management 259: 1127-1134. - doi: 10.1016/j.foreco.2009. 12.027

Jehl H (2001). Die Waldentwicklung nach Windwurf in den Hochlagen des Nationalparks Bayerischer Wald [Forest development after windthrow in high elevations of the Bavarian Forest National Park]. In: "Waldentwicklung im Bergwald nach Windwurf und Borkenkäferbefall". Hrsg. Nationalpark Bayerischer Wald, Wissenschaftl. Reihe 14: 49-98. [in German]

Keidel S, Meyer P, Bartsch N (2008). Regeneration eines naturnahen Fichtenwaldökosystems im Harz nach großflächiger Störung [Regeneration of a natural Spruce forest ecosystem in the Harz Mountains after large scale disturbances]. Forstarchiv 79: 187-196. [in German]

Kozulko G (2002). Sanitation clear-cutting in Belovezh forest. Russian Conservation News 30: 24-26.

Krauchi N, Brang P, Schönenberger W (2000). Forests of mountainous regions: gaps in knowledge and research needs. Forest Ecology and 
Management 132: 73-82. - doi: 10.1016/So3781127(00)00382-0

Kulakowski D, Veblen TT (2003). Subalpine forest development following a blowdown in the Mount Zirkel Wilderness, Colorado, USA. Journal of Vegetation Science 14 (5): 653-66o. - doi: 10.1111/j.1654-1103.2003.tbo2197.x

Kulakowski D, Bebi P (2004). Range of variability of unmanaged subalpine forests. In: "Forum für Wissen 2004. Protection Forests and Natural Hazards". WSL, Birmensdorf, Switzerland, pp. 47-54.

Kuuluvainen T (2002). Natural variability of forests as a reference for restoring and managing biological diversity in boreal Fennoscandia. Silva Fennica 36 (1): 97-125.

Kuuluvainen T, Syrianen K, Kalliola R (2002). Logs in a pristine Picea abies forest: occurrence, decay stage distribution and spatial pattern. Ecological Bulletins 49: 105-113.

Kuuluvainen T, Kalmari R (2003). Regeneration microsites of Picea abies seedlings in a windthrow area of a boreal old-growth forest in southern Finland. Annales Botanici Fennici 40: 401-413. [online] URL: http://www.jstor.org/sta ble/23726798

Kuuluvainen T, Aakala T (2011). Natural forest dynamics in boreal Fennoscandia: a review and classification. Silva Fennica 45 (5): 823-841. doi: 10.14214/sf.73

Kölling C, Zimmermann L, Walentowski H (2007). Klimawandel: was geschieht mit Buche und Fichte? [Climate change: what happens with beech and spruce?] Entscheidungshilfen für den klimagerechten Waldumbau in Bayern. AFZ/Der Wald 62: 584-588. [in German]

Lässig R, Egli S, Odermatt O, Schönenberger W, Stöckli B, Wohlgemuth T (1995). Beginn der Wiederbewaldung auf Windwurfflächen [Start of revegetation on windthrow areas]. Schweizerische Zeitschrift Forstwesen 146 (11): 893-911. [in German]

Lässig R, Schönenberger W (2000). Nach "Lothar" und "Vivian". Erfahrungen profitieren [Learning from experiences after "Lothar" and “Vivian”]. Wald und Holz 81: 31-35. [in German] Leuschner C, Ellenberg H (2017). Ecology of central European forests. SpringerNature, Switzerland, pp. 972. - doi: 10.1007/978-3-319-43042-3

Moćalov SA, Lässig R (2002). Development of two boreal forests after large-scale windthrow in the Central Urals. Forest Snow and Landscape Research 77(1/2): 171-186. [online] URL: http://www.issw.ch/dienstleistungen/publikatio nen/pdf/4748.pdf

Motta R, Morales M, Nola P (2006). Human landuse, forest dynamics and tree growth at the treeline in the Western Italian Alps. Annals of Forest Science 63: 739-747. - doi: 10.1051/forest: 2006055

Newton AC (2007). Forest ecology and conservation. Oxford University Press, New York, USA, pp. 471. [online] URL: http://books.google.com/ books?id=I4ISDAAAQBAJ

Niklasson M (2002). A comparison of three age determination methods for suppressed Norway spruce: implications for age structure analysis. Forest and Ecology Management 161: 279288. - doi: 10.1016/S0378-1127(01)00500-X

Oliver CD (1981). Forest development in North America following major disturbances. Forest
Ecology and Management 3: 153-168. - doi: 10.1016/0378-1127(80)90013-4

Ostrofsky A, Jellison J, Smith KT, Shortle WC (1997). Changes in cation concentrations in red spruce wood decayed by brown rot and white rot fungi. Canadian Journal of Forest Research 27: 567-571. - doi: 10.1139/x96-188

Panayotov M, Kulakowski D, Larnjeiro Dos Santos L, Bebi P (2011a). Wind disturbances shape old Norway spruce-dominated forest in Bulgaria. Forest Ecology and Management 262: 470-481. - doi: 10.1016/j.foreco.2011.04.013

Panayotov M, Dimitrov D, Yurukov S (2011b). Extreme climate conditions in Bulgaria - evidence from Picea abies tree rings. Silva Balcanica 12 (1): $37-46$.

Panayotov M, Georgiev D (2012). Dynamics in the Ips typographus outbreak following the 2001 windthrow in Bistrishko branishte Reserve, Bulgaria. Silva Balcanica 13 (1): 38-48.

Panayotov M, Bebi P, Tsvetanov N, Alexandrov $\mathrm{N}$, Laranjeiro L, Kulakowski D (2015). The disturbance regime of Norway spruce forest in Bulgaria. Canadian Journal of Forest Research 44: 1143-1153. - doi: 10.1139/cjfr-2014-0505

Pavlov D, Tashev A, Dimitrov M (1999). Ordination of plant communities of Norway spruce forests in the Bistrishko branishte forest reserve. Research papers of the University of Forestry, section Forestry, Sofia, Bulgaria, vol. 38, pp. 29-33. [in Bulgarian]

Raev I, Georgiev N, Rosseva L, Baikov B (1987). Tree-ring investigations of Picea abies forests in Parangalitsa biosphere reserve. In: Proceedings of the "Task Force Meeting on Methods of Dendrochronology: East/West approaches". Krakow (Poland) 2-6 June 1986, vol. 1, pp. 195206.

Reimoser F, Armstrong H, Suchant R (1999). Measuring forest damage of ungulates: what should be considered. Forest Ecology and Management 120: 47-58. - doi: 10.1016/S0378-1127 (98)00542-8

Rohner B, Bugmann H, Bigler C (2013). Towards no-destructive estimation of tree age. Forest Ecology and Management 304: 286-295. - doi: 10.1016/j.foreco.2013.04.034

San-Miguel-Ayanz J, De Rigo D, Caudullo G, Houston Durrant T, Mauri A (2016). European atlas of forest tree species. Publication Office of the European Union, Luxembourg. - doi: $10.2788 / 038466$

Seidl R, Schelhaas MJ, Lexer MJ (2011). Unraveling the drivers of intensifying forest disturbance regimes in Europe. Global Change Biology 17: 2842-2852. - doi: 10.1111/j.1365-2486.2011. 02452.x

Schelhaas MJ, Nabuurs GJ, Schuck A (2003). Natural disturbances in the European forests in the 19th and 20th centuries. Global Change Biology 9: 1620-1633. - doi: 10.1046/j.1365-2486.2003.00 684. $\mathrm{x}$

Schönenberger W (2002). Post windthrow stand regeneration in Swiss mountain forests: the first ten years after the 1990 storm Vivian. Forest Snow and Landscape Research 77: 61-80. [online] URL: http://www.bf.uni-lj.si/fileadm in/groups/2716/downloads/Č Oanki_vaje/Schone nberger_2002.pdf

Schönenberger W, Wasem U (1999). Der Beginn der Wiederbewaldung von Sturmwurfflächen im Gebirge. Ein Zwischenbericht [Start of revegetation on windthrow areas in the mountains. An intermediate report]. Forstliche Forschung ber Münch 176: 102-110. [in German] Skogsstyrelsen (2005). The storm in Sweden and measures taken by the Swedish forest administration. National board of forestry, 25 January 2005, pp. 1-2.

Siegrist J (2000). Natürliche Wiederbewaldung und Struktur eines ungeräumten Fichten-Windwurfs auf potentiellem Bergmischwaldstandort im Nationalpark Berchtesgaden [Natural regeneration and structure of an uncleared Spruce windthrow on a potential mixed mountain forest site in Berchtesgaden National park]. In: Nationalparkverwaltung Berchtesgaden (Hrsg) Waldentwicklung im Nationalpark Berchtesgaden von 1983 bis 1997. Nationalpark Berchtesgaden Forschungsbericht 43: 93-146. [in German]

Stancioiu P, O’Hara K (2006). Morphological plasticity of regeneration subject to different levels of canopy cover in mixed-species, multiaged forests of the Romanian Carpathians. Trees 20: 196-209. - doi: 10.1007/s00468-0050026-2

Stokes MA, Smiley TL (1996). An introduction to tree-ring dating. The University of Arizona Press, Tuscon, USA, pp. 73. [online] URL: http:// books.google.com/books?id=SvBF2Ora-eUC Svoboda M, Fraver S, Janda P, Bace R, Zenáhliíková J (2010). Natural development and regeneration of a central European montane spruce forest. Forest Ecology and Management 260: 707-714. - doi: 10.1016/j.foreco.2010.05.027 Svoboda M, Janda P, Nagel TA, Fraver S, Rejzek J, Bače R (2011). Disturbance history of an oldgrowth sub-alpine Picea abies stand in the Bohemian Forest, Czech Republic. Journal of Vegetation Science 23 (1): 86-97. - doi: 10.1111/j.16541103.2011.01329.x

Svoboda M, Janda P, Nagel TA, Fraver S, Rejzek J, Mikoláš M, Douda J, Boublik K, Samonil P, Cada V, Trotsiuk V, Teodosiu M, Bouriaud O, Biris Al, Sykora O, Uzel P, Zelenka J, Sedlak V, Lehejcek J (2014). Landscape-level variability in historical disturbance in primary Picea abies mountain forests of the Eastern Carpathians, Romania. Journal of Vegetation Science 25: 386-401. - doi: 10.1111/jvs.12109

Temperli C, Bugmann H, Elkin C (2013). Crossscale interactions among bark beetles, climate change, and wind disturbances: a landscape modeling approach. Ecological Monographs 83: 383-402. - doi: 10.189o/12-1503.1

Tjoelker M, Boratynski A, Bugala W (2007). Biology and ecology of Norway spruce. Forestry Sciences vol. 78, Springer, Dordrecht, The Netherlands, pp. 474. [online] URL: http:// books.google.com/books?id=TpzmSifHNyoC Trotsiuk V, Svoboda M, Janda P, Mikoláš M, Bače R, Rejzek J, Samonil P, Chaskovskyy O, Korol M, Myklush S (2014). A mixed severity disturbance regime in the primary Picea abies (L.) Karst. forests of the Ukrainian Carpathians. Forest Ecology Management 334: 144-153. - doi: 10.101 6/j.foreco.2014.09.005

Tsvetanov N, Panayotov M (2013). Age structure and historical development of forests in "Bistrishko branishte" Biosphere Reserve in Vitosha Mountain (Bulgaria). Ecologica Balkanica 5 (1): 
129-136.

Ulanova NG (2000). The effects of windthrow on forest at different spatial scales: a review. For est Ecology and Management 135: 155-167. - doi: 10.1016/S0378-1127(00)00307-8

Veblen TT (1992). Regeneration dynamics. In: "Plant Succession: Theory and Prediction" (Glenn-Lewin DC, Peet RK, Veblen TT eds). Chapman and Hall, London, UK, pp. 152-187. [online] URL: http://books.google.com/books? id=N3kyrwCznc8C

Vodde F, Jogiste K, Gruson L, llisson T, Koster K (2010). Regeneration in windthrow areas in hemiboreal forests: the influence of microsite on the height growths of different tree species. Journal of Forest Research 15 (1): 55-64. - doi: 10.1007/s10310-009-0156-2

Wohlgemuth T, Kull P, Wüthrich H (2002). Disturbance of microsites and early tree regeneration after windthrow in Swiss mountain forests due to the winter storm Vivian 1990. Forest Snow and Landscape Research 77 (1/2): 17-47. [online] URL: http://www.researchgate.net/publication/ 228736480

Zielonka T (2006). When does dead wood turn into a substrate for spruce replacement? Jour- nal of Vegetation Science 17: 739-746. - doi: 10.1111/j.1654-1103.2006.tb02497.x

Zielonka T, Holeksa J, Fleischer P, Kapusta P (2010). A tree-ring reconstruction of wind disturbances in a forest of the Slovakian Tatra Mountains, Western Carpathians. Journal of Vegetation Science 21 (1): 31-42. - doi: 10.1111/j.16 54-1103.2009.01121.x

Zywiec M, Ledwon M (2008). Spatial and temporal patterns of rowan (Sorbus aucuparia L.) regeneration in West Carpathian subalpine spruce forest. Plant Ecology 194: 283-291. - doi: 10.1007/s11258-007-9291-z 